\title{
Хиландар и његова „Средња библиотека“
}

\author{
Жарко Војновић \\ Народна библиотека Србије, Београд \\ zarko.vojnovic@nb.rs
}

\begin{abstract}
Сажетак
Хиландарска библиотека подељена је у три целине, физички одвојене, засноване на различитим карактеристикама књига, разврстаних по хронолошком и формалном начелу. Тема овог рада је тзв. Средња библиотека, која је до данас, као целина, потпуно непозната јавности. Она садржи највећим делом књиге руског порекла, штампане црквенословенским језиком, у распону од 17. до 20. века. Оне су највећим делом богослужбене, а знатан је удео и „књига за читање". Само мали део збирке је на руској грађанској ћирилици, а као подзбирка постоји и српска књига 18. века. Сви саставни делови Средње библиотеке укратко су описани у својим основним елементима, а изложена је и кратка историја њене обраде од седамдесетих година прошлог столећа.
\end{abstract}

Кључне речи: Манастир Хиландар, Средња библиотека, руска књига, богослужбена књига, црквенословенски језик српска књига 18. века, Народна библиотека Србије, библиотекари

\section{Хиландарска библиотека - прамајка свих српских библиотека}

Хиландар је крајеугаони камен српског идентитета каквог данас познајемо у његовом вишестолетном трајању, а хиландарска библиотека прамајка је свих српских библиотека, оних које данас постоје и оних које су током претходних векова нестале. На срећу, и упркос несретној историјској судбини материјалног дела српског културног наслеђа, она се још увек може видети у свом сјају, таман онолико да можемо познати каква је то сила морала бити за свог најлепшег цветања у средњем веку. Хиландарска библиотека слична је планини са видљивим геолошким слојевима, који одсликавају фазе њеног обликовања у дугом времену. Жели ли неко сагледати на једном месту историју српске књиге, моћи ће то учинити на српском делу Свете Горе.

Како се подизао Хиландар, тако се подизала и његова библиотека: њихов раст је упоредан. То је зато што манастир без библиотеке не постоји. Обавеза одржавања непрестане молитве, целокупног круга богослужења у свим његовим циклусима - дневном, недељном, годишњем, пасхалном - подразумева постојање обавезне збирке књига као станишта неизбројиве масе молитвених текстова потребних за његово ваљано испуњавање по слову устава. Стога се манастир без библиотеке не да замислити те је обавеза ктитора била да, заједно са подизањем цркве и потребних других здања, опреми и библиотеку, а на игуману и братству остајало је да је допуњавају и даље развијају. ${ }^{1}$ Царске лавре попут Хиландара, које су осим главне цркве добијале временом и друга молитвена места за савршавање евхаристије, како у кругу манастира у виду параклиса, тако и ван њега у облику келија и скитова, морале су због тога по броју потребних књига далеко испредњачити испред других, мањих манастира, а ако су имали срећу да макар у некој мери остану поштеђени од ратних разарања, у њима се током векова могао сабрати заиста велик број књига. Хиландар је, нажалост, у српској историји по томе готово изузетак: немањићки манастири одавна више не поседују књиге које би биле њихови

1 О феномену манастирских библиотека: Жарко Војновић, Срйске манасйирске библиош̄еке gо краја XVIII века (Панчево: Градска библиотека, 2019). 
савременици, а и оне које потичу из старијег средњовековног раздобља углавном нису настале у њима или за њих; велики број тих манастира више нема нити једну рукописну књигу. Хиландарска библиотека се, противно томе, сачувала, мада у релативном смислу. Иако више нема ни трага од књига које су представљале њено најстарије језгро, што је и логично, јер је књиге које су у непрестаној употреби готово немогуће сачувати од пропадања, ипак она у својој целини показује како је морала изгледати библиотека једног великог манастира и још више како се током векова развијала, са свим својим менама, падовима и успонима.

И због свих тих развојних етапа кроз које је прошла и сачувала свој дух неокрњен, иако су се небројене књиге расуле не само широм српског простора, већ и широм света, хиландарска библиотека је у неком смислу теоретски појам. Она, наиме, у просторном и у организационом смислу није јединствена, нити то може бити. Као што је речено, само постојање више молитвених средишта у самом манастиру или везаних за манастир и проистеклих из њега, подразумева постојање више засебних збирки књига, пре свега богослужбених. Све оне у правном смислу припадају манастиру, али су распоређене каткад и километрима далеко од њега те је до њих у давно доба требало потрошити, идући пешке, већи део дана, попут Карејске испоснице, која данас има своју посебну, прилично велику библиотеку. Појам хиландарске библиотеке стога је, може се рећи, конструкција са више слојева, историјских улаза и излаза. Данас под тим именом углавном подразумевамо књиге које су смештене у самом манастиру. Међутим, ни оне немају своје јединствено станиште, него су подељене у три основне целине, које одражавају управо историјски ход самог манастира и развојне етапе историје српске књиге, које одговарају са своје стране основним фазама културног развоја самог народа. Ове целине дефинисане су релативно скоро, пре неких пола века, кад су стручњаци Народне библиотеке Србије, предвођени Димитријем Богдановићем, започели систематски рад на уређењу затечене масе манастирских књига. У прву, која је свакако најважнија и коју можемо назвати Старом библиотеком, смештени су рукописи и рана штампана српска књига (15-17. век). Нова библиотека формирана је од новијег слоја књига, оних које нису старије од 19. века, на свим језицима: тај део библиотеке и данас се развија и доступан је и самим монасима и посетиоцима манастира. Између њих две угнездила се Средња библиотека, до данас готово потпуно непозната научној јавности, па и већини самих Хиландараца. Стару библиотеку доступном је учинио Димитрије Богдановић, сво-

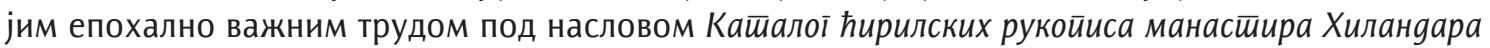
(1978), који у свом другом тому садржи и Палеоїрафски албум. Овај каталог узорно је и до данас непревазиђено дело српске науке на пресеку археографије и палеографије са општом историјом српске књиге и библиотека. И Нова библиотека у свом већем делу позната је јавности преко два каталога која је Народна библиотека Србије издала крајем прошлог и почетком овог века. ${ }^{2}$ Међутим, Средња библиотека још је сасвим анонимна. Овај рад је први глас о њој као целини. ${ }^{3}$

\section{Средња библиотека}

Основне збирке хиландарске библиотеке обликоване су комбиновањем хронолошког и формалног начела, која нису, због специфичности затечене грађе, могла бити спровођена дословно и доследно, па међу њима има знатних преклапања. Штавише, до њих је обавезно морало доћи. Рукописне књиге као најстарије и најважније морале су бити окупљене на једно место, али то не значи да је ова збирка искључиво средњовековног обухвата и карактера.

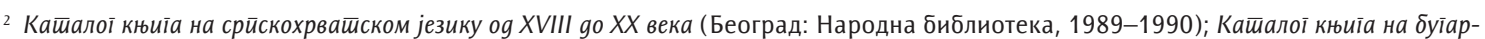
ском и руском језику: og XIX go XX века (Београд: Народна библиотека, 2004).

3 Основни подаци о њеном формирању у општим цртама изнети су у зборнику са стручног скупа одржаног почетком октобра у Краљеву, посвећеног сарадњи библиотека са црквама и верским заједницама. - Жарко Војновић, „Народна библиотека Србије и штампана књига манастира Хиландара“, у Сараgња библиошека са библиошеекама шраяииионалних иркава и верских зајеgнииа у Рейублици Србији: зборник раяова сйручної скуйа (Краљево: Народна библиотека "Стефан Првовенчани“, 2020), 89-99.
} 
3бог продужавања праксе преписивања књига које се нису могле наћи у штампаном виду, она садржи и рукописе настале дубоко у 19. веку; са друге стране, основу Нове библиотеке чине књиге штампане и у манастир донесене управо у том столећу. Средња библиотека преклапа се са своје две сестре на оба своја хронолошка краја, о чему ће даље бити речи. ${ }^{4}$

Како је Средња библиотека уопште настала? Рекло би се да је она у неком смислу формирана од књига преосталих после уобличавања Старе и Нове библиотеке, које су у оно доба, кад у Хиландар стиже научна и стручна експедиција из Србије под водством Димитрија Богдановића, добиле приоритет. Устројавање Старе библиотеке је свакако морало бити на првом месту, иако је с рукописном књигом било најтеже радити: тај део посла свакако је био научног карактера, а срећна околност је била да се тог посла прихватио управо Богдановић, вероватно једини који је у то доба био способан да се с њим ухвати у коштац. Са друге стране, како би се амортизовала тежина његовог подвига, библиотекари су се подухватили онога што је било релативно најлакше, а то је било издвајање новијих књига, издатих у 19. и 20. веку, са којима су се и иначе у свом раду сусретали те су били стручно обучени за руковање њима. Те две целине настале су тако највећим делом још седамдесетих година: Стара библиотека је затворена и доступна само научним и стручним радницима, док је Нова отворена и стоји на располагању свима и једина је која се и даље попуњава и носи обележје савремене библиотеке. Но, кад је окончано разврставање, испоставило се да постоји велики број књига које нити по једном критеријуму нису спадале у неку од ове две збирке. Од њих је управо створена Средња библиотека. Но не би требало мислити да је она прости преостатак без сопственог идентитета. Њен корпус састављен је углавном од штампаних књига које су у једном раздобљу почеле полако постајати све присутније у српским црквама и манастирима, да би на неким подручјима, попут Карловачке митрополије, већ у првој половини 18. века однеле бројчану превагу: то су руске богослужбене књиге. ${ }^{5}$

Тако и Средња библиотека поседује јасну физиономију. Њен средишњи део, велику већину, чини штампана нововековна руска књига. Под овим изразом подразумевамо књиге које су настале после реформе патријарха Никона, започете средином 17. столећа, после чега су у самој Русији све дотадашње рукописне и штампане књиге повучене из званичне црквене употребе. Овај процес, који је у Русији изазвао велики црквени раскол, до данас незалечен, одвија се у време кад Србима, великим делом због ратних разарања, непрестаних сеоба и сиромаштва проистеклог из тога, све више нестаје сопствених књига, насталих у духу српскословенске традиције, због чега одржавање богослужбеног живота постаје отежано. Производња рукописне књиге била је неефикасна, а српских штампарија већ одавна није било. Једини поуздан извор богослужбених књига - поуздан у смислу њихове непрестане продукције - била је Русија, са своја два велика издавачко-штампарска средишта: московским Печатним двором и Типографијом Кијевопечерске лавре. Руска књига је одговарала и нама, језик је био готово исти, а потребе у потпуности идентичне. Зато српски монаси већ од почетка 16. века путују у Русију по помоћ, па тако и Хиландарци врло рано, свакако пре 1581, одлазе на тај далеки пут и том приликом добијају велики псалтир са тумачењима и четири књиге беседа Јована Златоустог. ${ }^{6}$ Ово је први документовани случај пристизања руских књига у српску царску лавру; како је започело тада, тако ће се наставити и у наредним столећима. Исти процес одвијао се на целом српском етничком простору, како у традиционалним српским крајевима, тако и на просторима које Срби масовније насељавају у време османске окупације. Он ће се окончати потпуном русификацијом српских црквених библиотека, која ће на подручју Карловачке

\footnotetext{
${ }^{4}$ Овај текст настао је на основу личног увида у Средњу библиотеку, коју његов аутор обрађује од лета 2018. године, са прекидом у 2020. због околности изазваних пандемијом. Пошто је остало још много рада на њој, а могућности даљег напредовања у овом часу су сасвим неизвесне, овде нећемо бити у могућности да изнесемо егзактне бројке, што, на крају крајева, и није од пресудног значаја.

5 Војновић, Нав. дело, 241-245.

${ }^{6}$ Москва-Србија, Беоїраg-Русија, 1 (Београд: Архив Србије; Москва: Главное архивное управление города Москвы, 2013 ), 212.
} 
митрополије отићи дотле да ће само руске имати архијерејски благослов за употребу на богослужењима. ${ }^{7}$ Због тога ће српска књига све више нестајати из наших старих библиотека, а замењиваће је руска, која не само што ће постати многобројнија, него ће често остати и њихов једини садржај. То се завршило тиме што су данас те библиотеке препуне управо руске књиге 18. и 19. века, а многе немају више нити једну српску. Хиландар није могао бити изузетак. Прелазак на употребу руске књиге био је животно нужан и неопходан, а логична последица било је физичко нестајање српске књиге: пошто више није била, највише због оштећености, погодна за кориштење, она је постајала осуђена на животарење у неком мрачном углу манастирских конака, одакле је често, као неупотребљива, нетрагом нестајала. Управо је то разлог што је Средња библиотека много већа од Старе. Узмемо ли у обзир да су такви, неповољни по српску књигу услови, трајали неколико векова, право је чудо да нам се до данас било шта и сачувало. На срећу, хиландарски анђео чувар није дао да све пропадне, па су седамдесетих година из неколико манастирских скривница изрониле бројне рукописне књиге и велики број раних српских штампаних књига, због чега данас Стара библиотека манастира Хиландара има свакако највећи углед међу свим српским библиотекама. Она је, по свом пореклу, већински српска (уз нешто рукописа руске, бугарске, влашке и молдавске редакције) и зато у најбољем смислу одражава српски карактер овог манастира. Насупрот томе, Средња библиотека је већински руска, показујући на тај начин врло речито шта се дешавало са богослужбеним животом манастира још од 17. века и сведочећи метаморфозу коју су, уосталом, претрпеле све старије српске библиотеке. Очигледно је да је бројност руске богослужбене књиге била одлучујућа при формирању ове засебне целине, која се, као што је речено, од Старе библиотеке разликује својим пореклом, а од Нове околношћу да је у њој богослужбена књига већинска, које у Новој уопште и нема. Са друге стране, њено поклапање са садржајем Нове библиотеке је у хронолошком смислу евидентно, јер је огроман број руских књига у њој штампан у 19. и 20. веку. Тако бисмо основне карактеристике три засебне хиландарске библиотеке могли, не рачунајући мање или веће изузетке, исказати овако: Стара библиотека је српска, Средња библиотека је руска, а Нова библиотека је небогослужбена, на многим језицима. Нагласимо и ово: иако пореклом руска, Средња библиотека није и језички руска, него црквенословенска. ${ }^{8}$ Стари заједнички језик словенског богослужења суверено је владао све до најновијег времена и међу Србима, штавише тако је највећим делом и у ово време, па је употреба тзв. српског народног још увек ограничена на онај део „гласног“ обраћања свештеника народу, док је поезија - садржај богослужбених књига - готово стопроцентно остала у старом језичком руху. ${ }^{9}$

Средња библиотека је, због свог статичног карактера и вредности које садржи, замишљена попут Старе, као музејска збирка. Иако је по типу чуварка богослужбене књиге, а по пореклу руска, она има и друге садржинске карактеристике, статистички можда маргиналне, али по значају врло истакнуте. Наиме, при класификацији затечених књига у манастиру и при одлучивању које ће у коју збирку ићи, појавиле су се и мање целине, које су морале наћи одговарајуће место, иако то није било лако решити, јер по својим одликама нису задовољавале основне критеријуме формирања посебних целина о којима смо горе говорили. То се пре свега тицало српске књиге 18. века: њој није било места у Старој библиотеци, која је по својој основи средњовековна, јер код Срба 18. век са становишта културе представља велики прелом, па је тако и развој српске књиге, тачније српског издаваштва и штампарства, кренуо тада сасвим новим путевима,

\footnotetext{
Војновић, Нав. дело, 235-241.

8 Осим књига на црквенословенском, она садржи и приличан број старијих штампаних књига на грчком, као и на неким другим језицима. Ове књиге засад нису у средишту наше пажње.

9 Данас се у Српској православној цркви српски читају само јектеније и јеванђелске перикопе, затим текстови из часослова и требника, ретко кад и нешто друго; напротив, у Хиландару се српски језик на богослужењу може чути изузетно ретко, па се чак и апостол и јеванђеље на литургији читају на црквенословенском. То најбоље сведочи о традицији везаности Хиландара за другу фазу развоја историје манастирског богослужења, тј. ону рускословенску, о којој најбоље сведочи садржај Средње библиотеке.
} 
коначно добивши нови изглед и понекад нови смисао. Ове књиге нису пристајале ни уз збирку Нове библиотеке, јер се својом вредношћу издвајају од оних на којима је она заснована. Тако је нађено решење које донекле нарушава смисао постојања Средње библиотеке као целине пре свега богослужбених књига, али одговара њеном музејском карактеру, па су све српске књиге 18. века прикључене њој. ${ }^{10}$ Штавише, како би се донекле неутрализовао руски карактер Средње библиотеке и нагласио српски карактер Хиландара, оне су физички смештене на сам њен инвентарски почетак. Њих нема много, свега четрдесетак наслова, али би требало имати на уму да српска осамнаестовековна књига није карактеристична за простор Свете Горе, која се налази ван традиционалне српске етничке територије, због чега није стајала на главним правцима њеног ширења, па је овакав број за Хиландар ипак значајан. Осим тога, ни већина манастира некадашње Карловачке митрополије не могу се похвалити већим бројем књига ове категорије, тако да Хиландар и овде остаје у самом врху, нарочито стога што се у тој подзбирци налазе многа важна, па и капитална дела српског стваралаштва и издаваштва тог времена: римнички и вене-

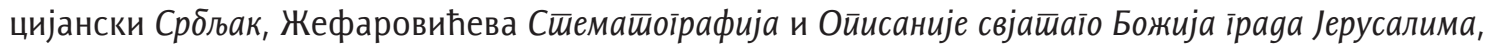

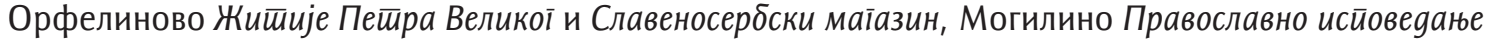

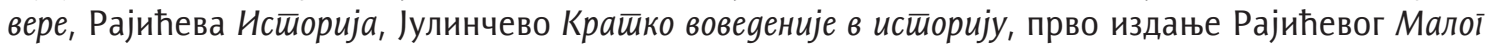

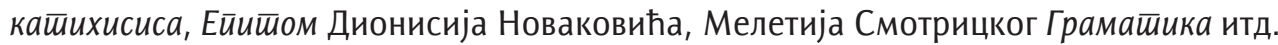

Средња библиотека смештена је на првом спрату јужног дела конака, тачно изнад Нове библиотеке, у условима који нису идеални, али су, у околностима обнове манастира после катастрофалног пожара, једини могући. Грађа је подељена у хронолошке групе: прва садржи руску књигу 17. века, друга 18. века, а трећа 19. и 20. века, што је нашло одраза и у инвентарно-сигнатурном обележавању. ${ }^{11}$ Из овога је јасно да њени уобличитељи себи нису могли задати горњу временску границу, тако да је ова збирка, због потребе да се све богослужбене књиге окупе на једном месту, дошла својим садржајем готово до наших дана. Требало би напоменути да се ради искључиво о неактивним књигама, оним које су због нечега повучене из употребе; па иако је речено да је овај фонд затвореног типа и да се даље не развија, може се ипак очекивати да у њега с времена на време стигну књиге које негде више нису потребне, као и да се, у случају поновног активирања неког од старијих скитова или келија, одатле позајме књиге потребне за богослужење (чему је сведок био и сам писац овог рада), што ову библиотеку, чак и при свој њеној дугогодишњој анонимности и скривености, ипак чини живом. Њена физиономија на најбољи начин у својој основи одражава карактер и намену места које је чува, а то је на првом месту богослужење - зато Средња библиотека, заједно са Старом као хронолошки примарном, омогућава заинтересованом литургичару да целокупну историју српског богослужења сагледа у Хиландару као ни на једном другом месту - и потом образовање личног духовног живота путем књиге. Ова двојност сасвим одговара основној једноставној подели која се може ефикасно применити на манастирске библиотеке: оне садрже, дакле, књиге за богослужење и књиге за читање. ${ }^{22}$ То је традиција целокупног православног монаштва, па је тако и део српског рукописног наслеђа, о чему сведочи не само хиландарска Стара библиотека, него и целокупан корпус српске рукописне књиге. Та традиција одржавана је и у епохи руске штампане књиге, што се јасно види на садржају Средње библиотеке. Не постоји нити један

\footnotetext{
10 При првој класификацији књига, из непознатих разлога је девет српских књига из 18. века смештено у Нову библиотеку, при чему се у неколико случајева ради чак о насловима који су већ постојали у Средњој библиотеци. Зато је и поменути каталог "српскохрватске“ књиге морао у свом наслову садржати временску одредницу везану за 18. век, што је био непотребан и лако решив пропуст.

11 Најстарија књига потиче ипак из 16. века; испоставило се да је досад неидентификовани Апостол на сигнатури 2.35 штампан 1574. у Лавову, у печатњи једног од првих руских штампара, московљанина Ивана Фјодорова, што је стога свакако највећа драгоценост Средње библиотеке. Најстарија пак књига 17. века је познати Служабник, настао 1604. у Стратину, у штампарији Фјодора Балабана (сигн. 2.51, сачувана само последња петина књиге).

12 Према класификацији Н. К. Никољског Ближайщія заgачи изученія gревне-русской книжносши (Санктпетербург: Общество любителей древней письменности, 1902), 6-7.
} 
богослужбени жанр који у њој није заступљен (служабници, часослови, октоиси, псалтири, триоди посни и цветни, минеји, требници...) и то у огромном броју издања и примерака, али са друге стране налазимо право мноштво „књига за читање“, где пре свега спадају најпре класични аутори и дела православне теологије, а потом и читав низ новијих руских богословских писаца, што чини Средњу библиотеку веома богатом. Осим тога, то је највећа и најразноврснија српска, премда по пореклу руска, збирка ове врсте, са којом се не може ни изблиза мерити оно што налазимо у другим српским манастирима. И ова чињеница, поред многих других, чини Хиландар изузетном појавом у српском монашком сазвежђу.

Без икакве сумње се може рећи да је Средња библиотека, као ризница црквенословенског језика, тврђава заједничког православног словенског идентитета, који се у тешка времена османске владавине чувао највише на овај начин - преко књига. Омогућити на тај начин суштинско живљење манастира значило је у то доба утемељити опстанак православних: историја сведочи да се народ и у најбоља и у најгора времена увек окупљао око својих светиња које су биле и ствар националног поноса и колективне самоспознаје. То се тиче и Хиландара: иако географски одвојен од етничке матице, он је вековима зрачио не само по читавом српском простору, него и широм православног света. Све то не би било могуће да је у њему, као што се дешавало са многим немањићким манастирима, утихнуло богослужење и нестао монашки живот. Средња библиотека је стога, за оне што умеју читати онај ћутљиви део српске повеснице, још увек један живи организам који показује оружје којим се, по нестанку царских ктитора и приложника, столећима водила невидљива духовна борба у име заједничке будућности и есхатолошких надања. Наравно, те битке су имале и лични карактер, у чему и јесте једна од суштинских манифестација монашког живота. Мноштво богословских списа штампаних у Русији омогућавало је српском монаху да одржава непрекинутим ланац православног теолошког предања, чији је један пол у богослужењу и испуњавању личног молитвеног правила, а други у бављењу богословљем на основу списа Отаца Цркве. Познато је да у времена „најезде варвара“, када пропадне не само државни организам, него се страшно заљуља и видљиво оштети и црквени, у опасност долази и духовни живот самих монаха, који најчешће остају без својих уточишта, без књига, често и без редовног духовног руковођења. Иако се литургија може служити и у шуми, а монах молити без престанка на сваком месту, искакање из редовног тока богословског предања може изазвати назадовање, као кад се плодан врт запусти и преда природним стихијама. Зато је богатство богословске књиге која је Србима почела стизати из Русије још у 17. столећу било највећа препрека запарложењу српских духовних засада. У Средњој библиотеци обитава право мноштво књига те врсте, од којих су многе темељна дела не само руског теолошког издаваштва и стваралаштва, него уопште и руске историје књиге, чак и из прениконовског доба. Већ тај најстарији део збирке руске књиге показује не само симбиозу богослужбеног и богословског начела Православне цркве, него и садејство светоотачке и нове руске теологије. Ту су, од дела Отаца Цркве, обавезне Златоустове беседе на Дела апостолска и Павлове посланице (Кијев, 1623, 1624; Москва, 1664), његова Кюиїа о свешиенсиву (Лавов, 1614; Москва, 1664), тумачења књиге Откривења Андреја Кесаријског (Кијев, 1625), Лесшвииа Јована Лествичника (Москва, 1647), Паренесис Јефрема Сиријског (Москва, 1647), чувени зборник превода са грчког Епифанија Славинецког (Москва, 1656), дела Аве Доротеја (Кијев, 1628)..., а затим долази читав низ нових малоруских теолога попут Димитрија Ростовског, Антонија Радзивиловског, Петра Могиле, Лазара Барановича, Инокентија Гизеља, Симеона Полоцког, Кирила Транквилиона, Јоаникија Гољатовског, Памве Беринде... Овако оборужан, хиландарски монах могао је бити способан да постане чврста карика православног богословског предања и да одржи монашки позив на нивоу који су поставили оснивачи манастира.

3бирка књига 17. века сама по себи није велика (мање од стотину), али је важна као сведочанство да је Хиландарско братство ишло у корак са својим добом, што у онаквим условима није било лако. Насупрот њој, збирка руске књиге 18. века већ достиже изузетну бројност, око 900 примерака. Она је сличног садржајног облика као и збирка 17. века, али се ипак јављају 
одређене промене, у складу са духом времена. Богослужбена књига још увек превладава, све је више зборника опширнијих и пролошких житија светих (у редакцији Димитрија Ростовског), библијских издања, све су бројнија дела класичне светоотачке литературе, али је удео новијих малоруских теолога опао на минимум, због генерално негативног става према њима, који у Московској патријаршији влада од краја 17. столећа те се њихове књиге више нису толико објављивале. Један од најопипљивијих израза нових кретања, насталих са петровским реформама почетком 18. столећа, јесте појава књига на грађанској ћирилици, међу којима је знатан број оних које не само да нису црквеног, него уопште религијског карактера, при чему је много превода са европских језика, што је уједно највидљивија карактеристика руске књиге 18. века. По овоме хиландарска библиотека личи на све друге библиотеке српских манастира, у које полако, током 18. века, све више продиру књиге секуларног карактера, што сведочи о томе и да се интересовања монаха донекле мењају; то ће се на крају окончати потпуном статистичком превлашћу књига нецрквеног садржаја у односу на традиционалне, што показује и Нова библиотека Хиландара, која је далеко најбројнија.

Збирка књига штампаних у 19. веку у Средњој библиотеци је најобимнија: она садржи близу 3000 примерака књига, а убројимо ли и бројне привезе, тај број прелази 3500 (има и нешто књига штампаних у 20. столећу, које су по карактеру могле припасти искључиво овде). И она је сличног духа као старије збирке, још увек налазимо обимна фолио издања богослужбених књига и дела Отаца Цркве, али већ на први поглед уочавамо индикативну појаву књижица џепног формата, којих је готово небројено мноштво. И оне су све руског порекла, великом већином на црквенословенском језику, а одражавају духовну климу тадашње Русије, у којој лична побожност мирјана има велику улогу, што је подржано огромном продукцијом књига малог формата, приступачних обичном свету, чак и сиромашнима; осим тога, оне су биле важан део православне мисије, јер су се и бесплатно могле делити. Део те атмосфере преливао се и на Србе, па тако и на монаштво те се и онај који не познаје духовне токове времена само на основу изгледа овог дела Средње библиотеке може с њима непосредно сусрести и упознати их. Између ових књижица не можемо пропустити да не споменемо бројне акатисте, који се као засебна издања мањег обима штампају у Русији још у 18. веку, али у 19. веку долази до праве поплаве акатиста џепног формата, при чему се у његовој другој половини то претвара у извесну духовну моду. Пошто су то редом биле књижице у папирном повезу, монаси су, а код њих је очито склоност ка акатистним службама била велика, по неколико њих, чак и по петнаестак, умели заједно повезивати у једне корице, правећи тако сопствене молитвене зборнике (што је, уосталом, средњовековна традиција, из доба рукописне књиге), чувајући их уједно од пропадања; у Средњој библиотеци смо тако успели набројати близу 400 наслова акатиста (рачунајући у овај број и многе дупликате).

Књиге данашње Средње библиотеке стизале су у Хиландар на познате начине, што можемо видети најбоље по рукописним записима у њима: неке су куповане, неке су поклањане у оквиру освештане приложничке традиције, не само од побожних Срба, него и од Руса. Велики део њих доспео је из личних монашких библиотека, према правилу које каже да имовина упокојених монаха остаје њиховом манастиру; та пракса одвија се све до данас, и пред нашим очима. О томе сведоче бројни потписи монаха на књигама, од давних времена до данас, неке књиге су дуго прелазиле из руке у руку док се коначно нису скрасиле заједно са свим другима; неки монаси су у новије време имали и сопствене једноставније печате. ${ }^{13}$ Но, Средња библиотека

\footnotetext{
13 Као и свака стара библиотека, и ова је права ризница података који прате историјски живот сваке поједине књиге. Ниједна књига коју овде налазимо нема значење пуке инвентарне јединице, него је понекад врло говорљиви сведок не само своје судбине, већ и судбине манастира у којем живи и људи који су је поседовали. Зато је неизоставно важно детаљно описати сваки примерак, при чему су свакако најбитнији рукописни записи, који често садрже описе догађаја о којима не знамо ништа, чак и из блиске прошлости, као што је опис пожара који је јула 1945. захватио околину манастира, заустављен саборном молитвом пред Тројеручицом изнесеном ван зидина манастира, или запис из марта 1948. о упаду „андарта“ (разбојника - ради се о грчким комунистима у време Грчког грађанског рата), који су опљачкали манастир. Оба записа се налазе у једном Новом завету малог формата. Каталог књига који садржи овакве и сличне податке није тек некакав бирократски списак књига, већ представља прави сценарио за документарни филм о животу манастира.
} 
има једну специфичност, која у правом светлу показује српско-руску духовну симбиозу, која је можда свој најдубљи израз доживела на Светој Гори. Наиме, на великом броју књига стоје рукописни записи који јасно казују да су оне, и то у недавној прошлости (мислимо ту на 19. век и почетак 20. века), биле не у српском, него у руском власништву, тачније - да нису биле у Хиландару: јасно се уочавају руска имена и презимена, не само монаха него и мирјана, исписиване су читаве реченице на руском (нпр. посвете) са веома блиским датумима, а уз то и многе књиге имају руске печате, што јасно сведочи да су се користиле у молитвеној и богослужбеној пракси руских светогорских цркава и руских монаха. Откуд, дакле, Хиландару књиге са печатом руске атонске келије Светог Јована Златоустог, руског скита Светог Илије, карејског скита Свете Тројице, итд.? Отуд што су све те келије и скитови, у ствари, сопственост Хиландара још из давних времена, али су због опадања српског монаштва у међувремену запустели; њих од 18. века полако насељавају руски монаси, који до Првог светског рата постају најбројнији на Светој Гори. Међутим, после Октобарске револуције руско светогорско монаштво доживљава страшан пад, па и те келије временом остају без становника. Оно што је иза њих остало, у овом случају књиге, по праву власништва пренесено је у Хиландар и смештено највећим делом у Средњу библиотеку, која се на тај начин знатно умножила, и бројчано и садржајно, учвршћујући свој руски карактер.

\section{Мисија библиотекара или ко ће уредити Средњу библиотеку}

Треба рећи понешто и о томе шта се, са стручне стране, покушавало учинити са Средњом библиотеком по њеном коначном уобличавању. Нажалост, то је једна од класичних наших прича о великим жељама, славним почецима и неславним завршецима. Димитрије Богдановић је тежину рада на Старој библиотеци, најнапорнијег и научно најодоговорнијег, успео изнети сам, но то су изузеци који се више не понављају и који као да данас добијају помало митски карактер. Нову библиотеку каталошки су углавном обрадили способнији радници Народне библиотеке, па су се после много мука појавили и штампани каталози српске, руске и бугарске књиге, чиме је део те збирке обнародован. Било је замишљено да се слично учини и са Средњом библиотеком. После прелиминарног прегледа 1977. године, њена обрада, која је подразумевала коначно интерно разврставање, израду инвентара и сигнирање, а потом исписивање каталошких листића који би касније послужили за издавање штампаног каталога, започела је 1978. године. Окосницу радне групе чинила су два тадашња врхунска српска библиотекара, Лаза Чурчић из Библиотеке Матице српске и Јанко Радовановић, теолог и историчар уметности запослен у Народној библиотеци Србије. Основни проблем који је стајао на путу ефикасног рада на овој збирци био је у образовању библиотекара. Наиме, насилни прекид са традиционалним образовањем и негативан однос према њему створен после Другог светског рата проузроковали су да библиотекари више не умеју читати црквену ћирилицу, а још мање разумети црквенословенски језик, без чега се рад на таквој врсти грађе не да ни замислити. То је био први отежавајући чинилац, који је унапред ограничавао ионако сужен избор међу стручним радницима. Стога је од самог почетка било извесно да ће се на овој збирци моћи ангажовати изузетно мали број библиотекара, па су се тако Чурчићу и Радовановићу, одличним познаваоцима старе књиге, придружила још само тројица. Све је додатно тежим чинио и начин рада у Хиландару, који се одвијао у боравцима дугим по месец дана, што никако није могло пријати онима којима је манастирска атмосфера била страна, као ни онима који нису могли или хтели ускладити своје навике са тим специфичним начином живота. Томе се придружила и добро позната социјалистичка навика неодговорног пландовања, због чега је сав посао, како то често бива, зависио од савести радника. Пошто Чурчић није могао редовно одлазити у Хиландар, испоставило се да је све остало пало на Јанка Радовановића (по његовим речима, Чурчић је обавио огроман посао). Из његових извештаја се види да је сам успевао урадити много више но преостала тројица; њега је то озлојеђивало, но много 
мање од чињенице да се, по свему судећи, тај нерад и неефикасност нису нарочито дотицали никога у Народној библиотеци. Радовановић је каталогизацију (много компликованију од рада на савременој књизи) обављао чак и на сопствену штету, остајући сам у манастиру и ван предвиђених рокова, што је његовом руководиоцу у Београду због нечега нарочито сметало, иако је од тога могло бити само опште користи (он је од Радовановића из неких неразумљивих разлога тражио да се из Хиландара врати заједно са свима за Београд, да ту састави извештај, па да се онда ако хоће поново враћа у Грчку, што је у оно време, због слабијих могућности путовања и строжијих услова уласка на Атос, било веома тешко извести, да се не помињу и лични трошкови путовања које би у том случају морао поднети). Управо захваљујући том његовом добровољачком напору и упркос опструкцијама, научна јавност је ипак могла упознати нешто од Средње библиотеке, јер је Радовановић у два наврата објављивао каталог делова те збирке. ${ }^{14}$ Нажалост, изгледа да ни то није помогло да стекне поштовање и заслужи одговарајући статус. Међутим, чини се да је највећу препреку довршавању овог посла представљало скандалозно понашање појединих радника Народне библиотеке које се настављало из године у годину и веома саблажњавало монахе, што је на крају довело до губљења поверења хиландарског братства у њихове добре намере, па су коначно морали дати до знања да неки више не би требало да долазе у Хиландар. У званичној документацији о раду у Хиландару, сачуваној у архиви Библиографског одељења Народне библиотеке Србије, о тим неподопштинама нема, наравно, ни трага, али Радовановићеви извештаји, који одишу горчином, прилично детаљно откривају шта се заиста збивало, не избегавајући ни именовање главних виновника разних изгреда који, по његовом мишљењу, наносе срамоту и држави и државној установи. Њему је, осим тога, као веома одговорном и скромном човеку сметало и што се на нераднике троше толике дневнице, док се њему брани чак и да о свом трошку надокнађује њихову леност. То је тако трајало до 1983. године, кад је рад на Средњој библиотеци потпуно заустављен: не могавши више издржати такав третман нити гледати шта се по Хиландару чини, Радовановић прелази у Балканолошки институт, а Народна библиотека Србије остаје без јединог стручњака способног да се бави старом књигом уопште. ${ }^{15}$ Иза њега је, осим поменутих каталога у Археоїрафским йрилозима, остао обиман радни материјал у облику ручно писаних каталошких листића, великим делом већ редигованих и спремних за штампу. Но више није било никога ко би могао том послу одговорити. Испоставило се да је у свему деловао известан духовни закон који не допушта да људи неодговарајућег духовног настројења, који у средњовековне светогорске манастире улазе као страна тела, доживљавајући боравак у њима као прилику за распусно провођење годишњег одмора, получе икаквога успеха у раду, иначе добровољно прихваћеном (иако се на крају крајева ради о стручном послу), али да зато лако успевају уништити рад посвећеника.

Радовановићев каталошки материјал стајао је тако нетакнут на Библиографском одељењу више од деценије. Саิмо његово постојање морало је вероватно изазвати грижу савести код руководилаца; јасно је да ником није пријала нелагода због неокончаног посла за који је, уосталом, годинама издвајан велики новац, што би у нормалним околностима свакако требало правдати (мада пракса функционисања државних институција до данас сведочи супротно). Године 1996, поводом 800-годишњице Хиландара, поново се појавила идеја да се каталог Средње библиотеке доврши, а пошто у Народној библиотеци није било никог за то способног,

14 Јанко Радовановић, „Руске и румунске штампане књиге XVII века у Библиотеци манастира Хиландара“, Археоїрафски ӣрилози књ. 2 (1980): 229-325; Исти, „Руске књиге XVIII века штампане грађанском ћирилицом из библиотеке манастира Хиландара“, Археоїрафски ирилози књ. 6-7 (1984-1985): 355-423.

15 Радовановић је иначе у НБС (Библиографско одељење) био запослен на Срйској библиоірафији књиїа 1801-1867, па је његовим одласком готово сасвим заустављена и њена израда, да би била окончана тек 2019. (!), чиме је настала непоправљива и ненадокнадива двострука штета. Јасно је, дакле, да ни тада, као ни касније, руководство ове националне институције није имало готово никаквог осећаја за рад на штампаној старој књизи која представља, уз рукописе и рану штампану књигу, најважнији део њене збирке. Парадоксална и погубна политика ослањања на знања и способности једног човека наставља се све до данас. Недостатак системских решења све оставља судбини, тј. вољи и ентузијазму појединца, због чега се најважнији пројекти отежу у недоглед. 
позив је опет упућен Радовановићу. Овај, међутим, никако више није био вољан да се враћа у друштво у које се ни раније никако није могао уклопити и које је, по његовом мишљењу, било непријатељски расположено према њему (што и није за чуђење: добар радник увек смета нерадницима; између редова се да прочитати да је дискриминацију трпео и због свог тада непопуларног теолошког образовања). Осим тога, био је и свестан да би требало још много времена провести на терену; испоставило се да је у међувремену нетрагом нестао и велики део каталошких листића остављених на чување у Народној библиотеци Србије (!), због чега би те књиге требало обрадити испочетка. Упркос лошим искуствима, начелно је прихватио (иако одавна већ није био у најбољим годинама), али под условом да не иде заједно са радницима Народне библиотеке, који су, уосталом, оскудевали у знању и способностима, па од њих није могао имати икакве користи. ${ }^{16}$ Иако је очигледно да је Радовановићу било веома стало да своје дело оконча, на овоме је нажалост из нама непознатих разлога тада и остало, па је мисао о завршетку рада на овој збирци поново заћутала, на целу деценију. Тек 2006. у Хиландар се запутила нова група с намером да се она коначно обради; наравно, ново време донело је нове потребе и нову методологију, па је требало почети практично испочетка, а олакшавајућа околност била је што се могао обилато консултовати Радовановићев радни материјал, без којега многе књиге без насловних листова не би ни могле бити идентификоване. Но, на том једном покушају је и остало, ова се екипа више никад није поново сабрала, чему је вероватно допринело опште неискуство и недостатак воље код појединаца, због чега је морало проћи још једно потпуно јалово десетлеће, да би се рад обновио 2018, и то врло оптимистично - овај пут са само једним извршиоцем. Остаје да се види да ли српска библиотекарска заједница има довољно капацитета, пре свега духовног, да доврши рад на барем једном делу наслеђа хиландарске светиње, започет пре 44 године, у време кад је онај који ово пише тек требало да пође у школу, или ће Хиландар морати сачекати какав бољи народ и боље библиотекаре.

Како год било, он ће наставити да живи са истим смислом и циљем с којим је провео ових првих осам векова свога подвига, у непрестаној молитви. Има ли боље илустрације тог начина постојања од чињенице да је у Средњој библиотеци данас сачувано преко три стотине псалтира, књиге која, како написа утемељивач манастира, „никада не престаје“, 17 књиге с којом све почиње и све завршава, коју монаси не испуштају из руку и из свести, и која од самих почетака, већ два миленијума, обликује монашки однос према Створитељу и свету? Буде ли Хиландар проживео још многе векове, и буду ли се и даље користиле књиге, биће у њему још и других, нових библиотека о којима данас и не сањамо. Дужност библиотекара је да увек, шта год да се збива, буду сапутници и сарадници Хиландара, места одакле је српска књига потекла и куда непрестано увире.

\section{Извори и литература:}

1. Arhiva Bibliografskog odeljenja Narodne biblioteke Srbije (interni dokumenti).

2. Katalog knjiga na srpskohrvatskom jeziku od XVIII do XX veka. Beograd: Narodna biblioteka Srbije, 1989-1990.

3. Katalog knjiga na bugarskom i ruskom jeziku: od XIX do XX veka. Beograd: Narodna biblioteka Srbije, 2004.

\footnotetext{
16 Јанко Радовановић, Писмо Гвоздену Јованићу (председнику Хиландарског савета), 10. IX 1983; Недатирани извештај, упућен вероватно некоме из Хиландарског савета, по свој прилици 1983. године; Писмо Бошку Ђенићу, 21. II 1996. (архива Библиографског одељења, интерни документи). Намерно избегавамо навођење непријатних појединости из Радовановићевих извештаја, иако би оне одлично илустровале свест васпитаника комунистичке Србије у библиотекарској заједници и однос према културном наслеђу сопствених предака, што је свакако узрок тадашње пропасти овог пројекта.

${ }_{17}$ Свети Сава, Сабрана gела (Београд: СК3, 1998), 237.
} 
4. Moskva-Srbija, Beograd-Rusija, 1. Beograd: Arhiv Srbije; Москва: Главное архивное управление города Москвы, 2013.

5. Никољски, Николај Константинович. Ближаїшіја заgачи изученіја gревне-русскоі̂ книжносшии. Санктпетербург: Обшчество љубителеі̂ древнеі̂ пис'менности, 1902.

6. Radovanović, Janko. „Ruske i rumunske štampane knjige XVII veka u Biblioteci manastira Hilandara“, Arheografski prilozi knj. 2 (1980): 229-325.

7. Radovanović, Janko. "Ruske knjige XVIII veka štampane građanskom ćirilicom iz biblioteke manastira Hilandara" , Arheografski prilozi knj. 6-7 (1984-1985): 355-423.

8. Sveti Sava. Sabrana dela. Beograd: SKZ, 1998.

9. Vojnović, Žarko. „Narodna biblioteka Srbije i štampana knjiga manastira Hilandara“. U Saradnja biblioteka sa bibliotekama tradicionalnih crkava i verskih zajednica u Republici Srbiji: zbornik radova stručnog skupa, 89-99. Kraljevo: Narodna biblioteka "Stefan Prvovenčani“, 2020.

10. Vojnović, Žarko. Srpske manastirske biblioteke do kraja XVIII veka. Pančevo: Gradska biblioteka, 2019.

\title{
Hilandar and Its "Middle Library"
}

\begin{abstract}
Summary
The Library of the Hilandar Monastery is divided into three parts, physically separated based on different characteristics of the books classified according to the chronological and formal principles. The topic of this paper is the so-called "Middle Library" which has been, up to now, completely unknown to the public.

The books of today's Middle Library arrived in Hilandar in well-known ways: some were bought, and some were donated within the framework of a consecrated contributory tradition, not only by pious Serbs but also by Russians. Many of them come from personal monastic libraries, in accordance with the rule which says that the property of deceased monks remains in their monasteries. However, the Middle Library has a specificity that shows in the right light the Serbian-Russian spiritual symbiosis, which probably experienced its deepest expression on the Holy Mountain. Namely, a large number of books contain handwritten records clearly showing that they were, in the recent past (the nineteenth and the early twentieth century), Russian-owned, more precisely - that they were not in Hilandar: Russian names and surnames are clearly visible, not only of monks but also of laymen; entire sentences are written in Russian and many books have Russian seals, which clearly testifies that they were used in the prayer and liturgical practice of Russian churches and monks on Mount Athos. So, where did the Hilandar Monastery get the books with the seal of the Russian Athos cell of St. John Chrysostom, the Russian hermitage of St. Elijah, the Karyes hermitage of the Holy Trinity, etc.? All those cells and hermitages are, in fact, the property of Hilandar from ancient times, but due to the decline of Serbian monasticism, they have been abandoned in the meantime; since the eighteenth century, they have been slowly inhabited by Russian monks, who became the most numerous on the Holy Mountain until the First World War. However, after the October Revolution, the Russian monastic order of Mount Athos experienced a huge decline, so over time, those cells were left without inhabitants. What was left behind, in this case - books, was transferred to Hilandar by the right of ownership and placed mostly in the Middle Library, whose collection was thus significantly enriched both in quantity and content, strengthening its Russian character.

The Middle Library contains mainly books of Russian origin, printed in the Church Slavic language, in the period from the seventeenth to the twentieth century. They are mostly liturgical, but a significant part is made up of books to read. A small part of the collection is in Russian civil Cyrillic, and as a sub-collection, there are also Serbian books of the eighteenth century.

This paper describes, in brief, the component parts of the Middle Library and their basic elements, and presents a short history of the processing of its book collection, since the seventies of the last century.
\end{abstract}

Keywords: Hilandar Monastery, Middle Library, Russian books, liturgical books, Church Slavonic language, Serbian books of the eighteenth century, National Library of Serbia, librarians 